\title{
Penambahan alfa-tokoferol dalam pengencer susu skim - kuning telur terhadap kualitas spermatozoa domba Sapudi yang disimpan pada suhu $5^{\circ} \mathrm{C}$
}

\section{Addition of alpha-tocopherol in skim milk-egg yolk extender on the quality of Sapudi ram spermatozoa stored at $5^{\circ} \mathrm{C}$}

\author{
Satya Alysa Cahya Puspita ${ }^{1}$, Suherni Susilowati2 ${ }^{*}$, Soeharsono Soeharsono ${ }^{3}$, Trilas Sardjito ${ }^{2}$, \\ Abdul Samik ${ }^{2}$, Indah Norma Triana ${ }^{2}$ \\ ${ }^{1}$ Mahasiswa, ${ }^{2}$ Departemen Reproduksi Veteriner, ${ }^{3}$ Departement of Veterinary Anatomy, \\ Faculty of Veterinary Medicine, Universitas Airlangga. \\ * Penulis koresponden, e-mail: suhernifkhunair@gmail.com
}

\author{
Open access under CC BY - SA license, Doi : 10.20473/ovz.v9i3.2020.69-76 \\ Received October 31 2020, Revised November 30 2020, Accepted December 32020 \\ Published online December 62020
}

\begin{abstract}
Spermatozoa in fresh semen of Sapudi ram has a limited life span. The storage of semen in cold temperatures $\left(5^{\circ} \mathrm{C}\right)$ is intended to prolong the spermatozoa's life. However, storage in cold temperatures can lead to increased production of reactive oxygen species (ROS). This condition reduces the quality of spermatozoa. The purpose of this study was to determine the effect of alphatocopherol supplementation in skim milk-egg yolk extender on viability, motility, and plasma membrane integrity of Sapudi ram spermatozoa. Fresh semen derived from Sapudi ram was divided into four treatment groups. Control treatment (P0): semen was added in the extender of skim milkegg yolk without alpha-tocopherol. Three other treatments: P1, P2, and P3 semen were added in skim milk-egg yolk extender with the supplementation of $0.25,0.5$, and 1 gram alpha-tocopherol/ $100 \mathrm{~mL}$ extender, respectively. The results showed that the viability, motility, and integrity of the spermatozoa plasma membrane decreased gradually according to the storage length. Supplementation of skim milk-egg yolk extender with 0.5 gram of alpha-tocopherol/100 mL (P2) was able to maintain spermatozoa quality longer $(\mathrm{p}<0.05)$ than the control group. It can be concluded that alpha-tocopherol with a concentration of $0.5 \mathrm{~g} / 100 \mathrm{~mL}$ of skim milk-egg yolk extender effectively maintains the quality of Sapudi ram spermatozoa in storage at $5^{\circ} \mathrm{C}$.
\end{abstract}

Keywords: alpha-tocopherol, motility, plasma membrane integrity, Sapudi ram, viability

\section{PENDAHULUAN}

Kebutuhan masyarakat terhadap daging semakin meningkat dari tahun ke tahun. Pemenuhan kebutuhan daging tersebut tidak terbatas pada daging sapi saja tetapi juga daging domba. Domba merupakan hewan ternak yang banyak dipelihara masyarakat desa sebagai salah satu sumber pendapatan (Susilowati et al., 2010). Domba mudah dipelihara, murah dan mempunyai kemampuan reproduksi lebih tinggi dibanding ternak lainnya (Hardijanto et al., 2010). Dalam rangka meningkatkan produktivitas dan kualitas genetik ternak domba dapat dilakukan dengan inseminasi buatan. Semen didapat dari domba jantan unggul yang diseleksi dari populasinya. Semen yang berkualitas baik apabila motilitas spermatozoa lebih dari $70 \%$, sehingga layak untuk digunakan dalam proses inseminasi buatan (Susilawati, 2011).

Inseminasi buatan dapat dilakukan menggunakan semen segar, semen beku atau semen yang disimpan dingin pada suhu $5{ }^{\circ} \mathrm{C}$. Semen segar hanya bertahan 18 jam pada suhu kamar (Kusumawati et al., 2019), sedangkan 
semen beku domba sampai saat ini belum tersedia sampai ke pedesaan. Dengan demikian agar ejakulat dari seekor pejantan unggul dapat diergunakan untuk menginseminasi lebih banyak resipien dan dengan jangkauan wilayah yang lebih luas, penyimpanan semen pada suhu dingin dapat dipertimbangkan. Permasalahnnya adalah bahwa selama penyimpanan pada suhu dingin, kualitas spermatozoa menurun secara bertahap. Salah satu penyebab penurunan ini adalah reaksi reactive oxygen species (ROS) yang disebabkan dari aktivitas seluler, yang merusak komponen spermatozoa. Dua mekanisme utama ROS yang menyebabkan infertilitas adalah merusak membran plasma spermatozoa yang mengakibatkan penurunan motilitas dan merusak deoxyribonucleic acid (DNA) spermatozoa (Tremellen, 2008). Penambahan antioksidan dalam diluter diharapkan dapat mengurangi produksi ROS selama penyimpanan semen pada suhu dingin. Alfa-tokoferol merupakan salah satu bentuk vitamin E yang larut dalam lemak bersifat sebagai antioksidan yang mampu menangkap radikal bebas dan mencegah terjadinya reaksi berantai (Bebas, 2016). Penambahan alfatokoferol dalam pengencer sebagai sistem antioksidan membantu melindungi membran spermatozoa terhadap ROS (Ratnani et al., 2017).

Berdasarkan uraian di atas maka peneliti ingin meneliti tentang pengaruh penambahan alfa-tokoferol dalam pengencer susu skim kuning telur terhadap kualitas spermatozoa domba Sapudi yang disimpan pada suhu $5{ }^{\circ} \mathrm{C}$ dalam lemari pendingin.

\section{MATERI DAN METODE}

Penelitian ini dilakukan di Kandang Hewan Ternak Fakultas Kedokteran Hewan, Universitas Airlangga. Proses pengamatan sampel yang disimpan pada suhu $5^{\circ} \mathrm{C}$ berlangsung di Laboratorium Inseminasi Buatan, Fakultas Kedokteran Hewan, Universitas Airlangga. omba Sapudi dengan berat $45 \mathrm{~kg}$ dan usia 2-3 tahun. Domba Sapudi dalam keadaan sehat, dewasa kelamin, alat kelamin normal, dan libido yang baik. Teknik penampungan semen menggunakan vagina buatan, semen yang ditampung sebelum perlakuan terlebih dahulu dilakukan pemeriksaan makroskopis dan mikroskopis untuk mengetahui semen domba Sapudi tersebut layak atau tidak untuk diproses lebih lanjut. Pemeriksaan makroskopis meliputi pemeriksaan volume, warna, bau, $\mathrm{pH}$, dan konsistensi semen. Pemeriksaan mikroskopis meliputi viabilitas, motilitas, dan integritas plasma membrane.

\section{Pembuatan diluter}

Alfa-tokoferol murni (C29H50O2, Tokyo Chemical Industry) digunakan dalam penelitian ini. Larutan alfa-tokoferol dibuat dalam tiga macam konsentrasi dalam tween dan CMC-Na, yaitu $0,25 \mathrm{~g} / 100 \mathrm{~mL}, 0,5 \mathrm{~g} / 100 \mathrm{~mL}$, dan 1 $\mathrm{g} / 100 \mathrm{~mL}$.

Susu bubuk skim 10 gram dimasukkan ke dalam Beaker glass, ditambahkan aquades ad $100 \mathrm{~mL}$, diaduk hingga homogen dan dipanaskan sampai suhu $92-95^{\circ} \mathrm{C}$ selama 10 menit. Susu skim didinginkan hingga suhu kamar $32^{\circ} \mathrm{C}$, disaring dengan menggunakan kain kasa untuk membuang kepala susu. Telur segar disiapkan dan dibersihkan kulitnya dengan alkohol $70 \%$, dipecahkan kulit telur hingga 1/3-1/2 bagian dengan menggunakan pinset steril. Semua putih telur dibuang, sedangkan kuning telur yang utuh dan terbungkus selaput vitelin, dipindahkan diatas kertas saring atau kain kasa untuk menghilangkan putih telur yang tersisa. Selaput vitelin dipecah dengan batang pengaduk dan kuning telur dialirkan kedalam gelas ukur. Setiap tetesan kuning telur langsung jatuh ke dasar tabung agar dapat diukur volumenya dengan tepat. Kuning telur ditambahkan ke dalam air susu sebanyak 5\% (5 mL dalam 100 $\mathrm{mL}$ ). Penicilin $1000 \mathrm{IU} / \mathrm{mL}$ pengencer dan streptomicin $1 \mathrm{mg} / \mathrm{mL}$ pengencer ditambahkan kemudian diaduk hingga merata (Hardijanto et al., 2010).

Pengencer susu skim-kuning telur yang disiapkan dipisahkan menjadi empat tabung yang berbeda, masing-masing tabung reaksi berisi $1 \mathrm{~mL}$ pengencer. Konsentrasi penambahan alfa-tokoferol ke dalam setiap tabung didasarkan pada volume pengencer. Rasio volume semen terhadap pengencer adalah 1:10, oleh karena itu semen yang ditambahkan ke setiap tabung adalah $0,1 \mathrm{~mL}$ (Susilowati 
dkk., 2010) kemudian disimpan pada suhu 5 ${ }^{\circ} \mathrm{C}$.

Pemeriksaan 0 jam dilakukan tepat setelah pengenceran semen dan sebelum pendinginan. Pengamatan berlangsung setiap 24 jam mulai dari pendinginan pertama, dan berakhir setelah skor motilitas di bawah atau sama dengan $30 \%$.

\section{Pemeriksaan viabilitas spermatozoa}

Pemeriksaan dilakukan dengan meneteskan satu tetes semen dan satu tetes eosin negrosin pada permukaan gelas objek. gelas objek bersih lain digunakan untuk membuat apusan. Apusan dibiarkan kering di atas api bunsen burner (proses ini selesai dalam waktu 15 detik). Daya hidup spermatozoa diamati menggunakan mikroskop dengan perbesaran 400x. Hasilnya, warna spermatozoa yang mati berwarna merah muda keunguan, sedangkan spermatozoa yang hidup tidak terwarnai. Perhitungan persentase viabilitas spermatozoa adalah jumlah spermatozoa yang tidak terwarnai dibagi jumlah spermatozoa dihitung dikalikan seratus (Susilowati et al., 2010).

\section{Pemeriksaan motilitas spermatozoa}

Pemeriksaan motilitas spermatozoa dilihat dari pergerakan massa dan pergerakan individu spermatozoa. Gerak massa diamati dengan meneteskan satu tetes semen diatas gelas objek dan gerakan massa diamati di bawah mikroskop dengan perbesaran 100x. Penilaian gerak massa berdasarkan empat kriteria, yaitu +++ sangat baik, ++ baik, + sedang, dan 0 buruk. Gerak individu diamati dengan meneteskan satu tetes semen diatas gelas objek dan ditambahkan satu tetes larutan $\mathrm{NaCl}$ fisiologis, gelas objek ditutup dengan gelas penutup dan diperiksa dibawah mikroskop dengan perbesaran 400x. Penilaian gerak individu berdasarkan persentase arah gerak spermatozoa dan angka kecepatan gerak spermatozoa (Susilowati et al., 2010).

\section{Pemeriksaan integritas plasma membran spermatozoa}

Integritas plasma membran spermatozoa diamati dengan metode Hypo-osmotic Swelling Test (HOST) yaitu evaluasi respon spermatozoa (swelling dan non swelling) pada kondisi hipoosmotis. Pengamatan dimulai dengan memasukkan 0,1 mL semen dan 0,9 mL larutan HOST ke dalam tabung reaksi. Tabung reaksi diinkubasi pada suhu $37^{\circ} \mathrm{C}$ selama satu jam. Setelah inkubasi, satu tetes larutan diambil dan ditempatkan pada gelas objek. Satu tetes pewarna eosin negrosin ditambahkan pada gelas objek, dan apusan dibuat dengan prosedur yang sama seperti pemeriksaan viabilitas. Keutuhan membran spermatozoa diamati menggunakan mikroskop dengan perbesaran 400x. Dilihat spermatozoa dengan membran utuh ekor tampak membengkak atau melingkar, sedangkan membran spermatozoa yang rusak menunjukkan ekor tetap lurus. Perhitungan persentase integritas plasma membran spermatozoa adalah jumlah spermatozoa dengan ekor melingkar dibagi jumlah spermatozoa dihitung dikalikan seratus (Susilowati et al., 2010).

\section{Analisis data}

Data dianalisis menggunakan Analysis of Variance (ANOVA) Repeated measure jika terdapat interaksi $(\mathrm{p}<0,05)$ dilanjutkan dengan Duncan multiple range tests (Kusriningrum, 2008) menggunakan Statistical Product and Service Solution (SPSS) 20 untuk Windows.

\section{HASIL}

Karakteristik semen segar domba Sapudi hasil pemeriksaan makroskopis dan mikroskopis dapat dilihat pada Tabel 1 .

Tabel 1 Hasil pemeriksaan makroskopis semen segar domba Sapudi

\begin{tabular}{lc}
\hline parameter & karakteristik \\
\hline volume $(\mathrm{mL})$ & $1,18 \pm 0,26$ \\
warna & putih kekuningan \\
bau & normal khas \\
konsistensi & kental \\
pH & $6,75 \pm 0,45$ \\
viabilitas (\%) & $92,60 \pm 5.42$ \\
motilitas individu (\%) & $86,25 \pm 6.52$ \\
kecepatan & $3,75 \pm 0.45$ \\
konsentrasi (juta/mL) & $3775,00 \pm 625.24$ \\
integritas plasma & $54,25 \pm 11.46$ \\
membran (\%) & \\
\hline
\end{tabular}




\section{Viabilitas spermatozoa}

Tidak terdapat perbedaan yang signifikan diantara kelompok ( $p>0,05)$. Pemeriksaan selanjutnya dilakukan setelah penyimpanan pada suhu dingin $5^{\circ} \mathrm{C}$. Pada pemeriksaan 24 jam terlihat perbedaan yang signifikan antara P0 dan P1, dan antara P0 dan P2. Pada pemeriksaan 48 jam terlihat perbedaan yang signifikan pada $\mathrm{P} 0$ dan $\mathrm{P} 1$, antara $\mathrm{P} 0$ dan $\mathrm{P} 2$, dan antara P0 dan P3 (p <0,05). Pada pemeriksaan 72 jam perbedaan yang signifikan terlihat antara $\mathrm{P} 0$ dan $\mathrm{P} 1$, antara $\mathrm{P} 0$ dan $\mathrm{P} 2$, dan antara P0 dan P3 (p <0,05) (Tabel 2).

Tabel 2 Viabilitas spermatozoa domba Sapudi dalam penyimpanan pada suhu dingin dalam diluter susu skim-kuning telur dengan penambahan alfa-tokoferol

\begin{tabular}{ccccc}
\hline & \multicolumn{4}{c}{ viabilitas spermatozoa (\%) } \\
\cline { 2 - 5 } & 0 jam & 24 jam & 48 jam & 72 jam \\
\hline P0 & $77,53 \pm 6,1^{\text {a }}$ & $66,38 \pm 6,6^{\mathrm{a}}$ & $54,95 \pm 5,4^{\mathrm{a}}$ & $36,93 \pm 7,6^{\mathrm{a}}$ \\
P1 & $81,28 \pm 4,6^{\mathrm{a}}$ & $73,97 \pm 5,7^{\mathrm{b}}$ & $67,49 \pm 4,2^{\mathrm{bc}}$ & $56,14 \pm 3,3^{\mathrm{b}}$ \\
P2 & $80,36 \pm 5,9^{\mathrm{a}}$ & $75,69 \pm 4^{\mathrm{b}}$ & $69,19 \pm 2,6^{\mathrm{c}}$ & $60,62 \pm 4,3^{\mathrm{b}}$ \\
P3 & $78,19 \pm 5,3^{\mathrm{a}}$ & $72,07 \pm 4,6^{\mathrm{ab}}$ & $62,71 \pm 2,8^{\mathrm{b}}$ & $53,20 \pm 60^{\mathrm{b}}$
\end{tabular}

Superskrip yang berbeda pada kolom yang sama menunjukkan perbedaan nyata $(\mathrm{p}<0,05) ; \mathrm{P} 0=$ susu skim-kuning telur; P1, P2, P3= susu skim-kuning telur dengan suplementasi 0,$25 ; 0,5$; dan 1 gram alfa-tokoferol/100 $\mathrm{mL}$ diluter

Tabel 3 Motilitas spermatozoa domba Sapudi dalam penyimpanan pada suhu dingin dalam diluter susu skim-kuning telur dengan penambahan alfa-tokoferol

\begin{tabular}{ccccc}
\hline & \multicolumn{4}{c}{ motilitas spermatozoa (\%) } \\
\cline { 2 - 5 } & 0 jam & 24 jam & 48 jam & 72 jam \\
\hline P0 & $69 \pm 6,5^{\mathrm{a}}$ & $55 \pm 7,9^{\mathrm{a}}$ & $41 \pm 6,5^{\mathrm{a}}$ & $24 \pm 4,1^{\mathrm{a}}$ \\
P1 & $72 \pm 4,5^{\mathrm{a}}$ & $64 \pm 5,5^{\mathrm{b}}$ & $58 \pm 4,5^{\mathrm{b}}$ & $46 \pm 4,2^{\mathrm{bc}}$ \\
P2 & $73 \pm 5,7^{\mathrm{a}}$ & $66 \pm 4,2^{\mathrm{b}}$ & $59 \pm 2,2^{\mathrm{b}}$ & $51 \pm 4,2^{\mathrm{c}}$ \\
P3 & $71 \pm 6,5^{\mathrm{a}}$ & $62 \pm 4,5^{\mathrm{ab}}$ & $53 \pm 2,7^{\mathrm{b}}$ & $42 \pm 5,7^{\mathrm{c}}$ \\
\hline
\end{tabular}

Superskrip yang berbeda pada kolom yang sama menunjukkan perbedaan nyata $(\mathrm{p}<0,05)$; $\mathrm{P} 0=$ susu skim-kuning telur; P1, P2, P3= susu skim-kuning telur dengan suplementasi 0,$25 ; 0,5$; dan 1 gram alfa-tokoferol/100 $\mathrm{mL}$ diluter

\section{Motilitas spermatozoa}

Tidak ada perbedaan signifikan yang ditunjukkan diantara kelompok ( $p>0,05)$. Demikian pula idak ada perbedaan yang signifikan diantara ketiga perlakuan $\mathrm{P} 1, \mathrm{P} 2$ dan P3 ( $p>0,05)$. Pemeriksaan setelah pendinginan pada suhu $5^{\circ} \mathrm{C}$ menunjukkan perbedaan signifikan dari masing-masing kelompok ( $\mathrm{p}$ $<0,05)$. Pada pemeriksaan 24 jam perbedaan yang signifikan terlihat diantara P0 dan P1, dan diantara P0 dan P2 ( $\mathrm{p}<0,05)$. Pada pemeriksaan setelah 48 jam perbedaan yang signifikan terlihat pada P0 dan P1, diantara P0 dan P2 dan diantara P0 dan P3 ( $p<0,05)$. Pada pemeriksaan setelah 72 jam terlihat perbedaan yang signifikan diantara $\mathrm{P} 0$ dan $\mathrm{P} 1$, antara $\mathrm{P} 0$ dan P2, dan antara P0 dan P3 (p <0,05) (Tabel 2).

\section{Integritas plasma membran spermatozoa}

Terdapat perbedaan signifikan yang ditunjukkan diantara kelompok ( $p<0,05)$. Perbedaan signifikan terlihat antara P0 dan P2 (p <0,05). Pemeriksaan selanjutnya setelah dilakukan pendinginan. Terdapat perbedaan signifikan dari masing-masing kelompok ( $\mathrm{p}$ $<0,05)$. Pada pemeriksaan 24 jam terlihat perbedaan yang signifikan diantara P0 dan P2 (p <0,05). Pada pemeriksaan setelah 48 jam perbedaan yang signifikan terlihat antara P0 dan $\mathrm{P} 1$, diantara $\mathrm{P} 0$ dan $\mathrm{P} 2$ dan diantara $\mathrm{P} 0$ dan 
P3 (p <0,05). Pada pemeriksaan setelah 72 jam terlihat perbedaan signifikan diantara P0 dan P2

$(\mathrm{p}<0,05)($ Tabel 4).

Tabel 4 Integritas plasma membran spermatozoa domba Sapudi dalam penyimpanan pada suhu dingin dalam diluter susu skim-kuning telur dengan penambahan alfa-tokoferol

\begin{tabular}{ccccc}
\hline & \multicolumn{4}{c}{ integritas spermatozoa (\%) } \\
\cline { 2 - 5 } & 0 jam & 24 jam & 48 jam & 72 jam \\
\hline P0 & $41,40 \pm 3,6^{\mathrm{a}}$ & $32,66 \pm 2,6^{\mathrm{a}}$ & $24,32 \pm 2,5^{\mathrm{a}}$ & $13,25 \pm 3,4^{\mathrm{a}}$ \\
P1 & $45,20 \pm 3,6^{\mathrm{ab}}$ & $37,93 \pm 4,1^{\mathrm{ab}}$ & $30,59 \pm 3,3^{\mathrm{b}}$ & $18,70 \pm 3^{\mathrm{ab}}$ \\
P2 & $47,65 \pm 4,3^{\mathrm{b}}$ & $41,44 \pm 4,6^{\mathrm{b}}$ & $34,79 \pm 3,9^{\mathrm{b}}$ & $23,37 \pm 5,2^{\mathrm{b}}$ \\
P3 & $44,78 \pm 3,7^{\mathrm{ab}}$ & $37,40 \pm 4,3^{\mathrm{ab}}$ & $30,60 \pm 4,2^{\mathrm{b}}$ & $17,78 \pm 3,5^{\mathrm{a}}$ \\
\hline
\end{tabular}

Superskrip yang berbeda pada kolom yang sama menunjukkan perbedaan nyata $(\mathrm{p}<0,05)$; $\mathrm{P} 0=$ susu skim-kuning telur; P1, P2, P3= susu skim-kuning telur dengan suplementasi 0,$25 ; 0,5$; dan 1 gram alfa-tokoferol/100 $\mathrm{mL}$ diluter

\section{DISKUSI}

Hasil pemeriksaan semen segar domba Sapudi dalam penelitian ini menunjukkan volume 1,18 $\pm 0,26 \mathrm{~mL}$, konsentrasi 3775,00 \pm $625,24 \mathrm{juta} / \mathrm{mL}$, viabilitas $92,60 \pm 5,42 \%$, motilitas $86,25 \pm 6,52 \%$, dan integritas plasma membrane 54,25 $\pm 11,46$. Hasil tersebut lebih baik dibandingkan penelitian sebelumnya pada jenis domba yang sama, yaitu volume $0,96 \mathrm{~mL}$, konsenrasi $2780 \mathrm{juta} / \mathrm{mL}$, dan viabilitas hampir sama, yaitu 92,2\% (Immelda et al., 2019). Namun konsentrasi, viabilitas dan motilitas semen segar domba Sapudi penelitian ini lebih rendah daripada $5533 \mathrm{juta} / \mathrm{mL}, 93,3 \%$ dan 87,5\% (Arini et al., 2019).

Penyimpanan semen domba Sapudi pada suhu $5^{\circ} \mathrm{C}$ menunjukkan viabilitas, motilitas, dan keutuhan membrane menurun secara linier selama lima hari. Hasil tersebut sama dengan penelitian sebelumnya menggunakan semen jenis domba yang sama (domba Sapudi) dalam bahan pengencer kuning telur sitrat (Khoirunnisa et al., 2019), maupun menggunakan diluter dalam bahan pengencer susu skim - kuning telur (Swari et al., 2019). Pola perubahan parameter kualitas semen tersebut sama dengan yang terjadi pada semen sapi Simmental (Azura et al., 2020). Penambahan antioksidan ekstrak teh hijau (Camellia sinensis) (Khoirunnisa et al., 2019; Swari et al., 2019) pada bahan pengencer semen domba Sapudi, dan alfa-tocopherol pada semen sapi Simmental (Azura et al., 2020) terbukti dapat mengurangi kecepatan penurunan viailitas, motilitas dan integritas plasma membrane selama penyimpanan pada suhu $5^{\circ} \mathrm{C}$.

Kelangsungan hidup spermatozoa sangat dipengaruhi oleh komposisi lipid membran. Lapisan lipoid dari membran sel dapat mencegah zat yang tidak diinginkan memasuki sel. Kerusakan dan kehilangan lapisan lipoid ditemukan pada spermatozoa mati (Susilowati et al., 2010). Kerusakan yang diakibatkan oleh ROS pada membran plasma, menghasilkan kerusakan spermatozoa lebih lanjut. Setelah membran plasma rusak, ROS memasuki sel dan menyerang komponen seluler lainnya. Kondisi ini menyebabkan kematian spermatozoa. Viabilitas spermatozoa yang mengalami proses pendinginan dan pembekuan berkurang secara signifikan dibandingkan dengan semen segar (O'Connell et al., 2002).

Alfa-tokoferol bertindak sebagai antioksidan yang berfungsi meredam dampak negatif dengan mekanisme antioksidan pemutus rantai. Dengan penambahan alfa-tokoferol ke dalam media spermatozoa, maka peningkatan akumulasi produksi ROS oleh spermatozoa dapat dicegah, reaksi antara radikal hidroksil $(\mathrm{OH})$ dengan komponen asam lemak poli tak jenuh tidak terjadi, reaksi berantai tidak terjadi, peroksidasi lipid tidak terjadi. Akhirnya ikatan rantai-rantai asam lemak tidak putus dan senyawa aldehid termasuk malondialdehid (MDA) tidak terbentuk (Suryohusodo,2000). Akibatnya membran plasma spermatozoa yang berperan sebagai filter pertukaran zat-zat ekstra 
seluler dan intra seluler dalam proses metabolisme dapat dipertahankan dan kematian sel tidak terjadi (Garner dan Hafez, 2000).

Motilitas individu sangat terkait dengan keberadaan seminal plasma yang berfungsi sebagai sumber energi. Energi yang digunakan untuk motilitas spermatozoa berasal dari perombakan ATP di dalam mitokondria melalui reaksi-reaksi penguraiannya menjadi ADP dan AMP. Energi yang dihasilkan tersebut digunakan sebagai pergerakan (energi mekanik) atau sebagai biosintesis (energi kimiawi). Dalam semen terdapat empat bahan organik yang dapat dipakai secara langsung maupun tidak langsung oleh spermatozoa sebagai sumber energi untuk kelangsungan hidup dan motilitas spermatozoa, bahan-bahan tersebut berupa fruktosa, sorbitol, GPC dan plasmalogen (Susilawati, 2011). Pada proses fosforilasi oksidatif enzim-enzim yang berperan terletak pada membran dalam mitokondria. Pada proses fosforalisasi oksidatif, disamping energi bebas yang kemudian dikonversi menjadi molekul ATP, juga dihasilkan senyawa ROS. Salah satu penyebab utama kerusakan membran adalah ROS yang dihasilkan selama proses pendinginan semen. Reaksi berantai peroksidasi lipid yang didorong oleh ROS merusak membran mitokondria spermatozoa, yang mengakibatkan tidak hanya kerusakan membran tetapi juga penurunan fungsional. ROS terbentuk selama proses reduksi oksigen dalam fosforilasi oksidatif. Meskipun sistem pengikatan ROS ada dalam rantai transpor elektron, kebocoran elektron oleh komponen sebelumnya masih dapat terjadi (Halliwell dan Guttridge, 2015).

Tanpa penambahan antioksidan, motilitas menurun sampai kurang dari batas ambang $40 \%$ pada hari kedua penyimpanan (Vladika et al., 2019). Vitamin E memiliki kemampuan untuk menghentikan lipid peroksida dengan menyumbangkan satu atom hidrogennya dari gugus $\mathrm{OH}$ kepada lipid peroksida yang bersifat radikal sehingga menjadi radikal tocopheryl yang kurang reaktif dan tidak merusak (Hariyatmi, 2004). Radikal bebas bermula dari bentuk carbon-centered free radical, kemudian berikatan dengan oksigen bebas sehingga membentuk ROS. ROS dapat dinetralisir oleh lipid (polyunsaturated fat) menjadi hydroperoxide. Dalam menetralisir ROS lipid dibantu oleh vitamin E terutama tokoferol, dimana kemampuan tokoferol dalam menetralisir ROS lebih cepat bila dibandingkan dengan lipid. Terjadinya peroksidasi lipid pada membran sel dapat dicegah dan dikurangi oleh vitamin E (Jungwirth et al., 2016).

Pemeriksaan membran plasma utuh penting dilakukan karena kerusakan membran plasma akan berpengaruh terhadap motilitas dan daya hidup spermatozoa. Membran plasma spermatozoa dalam menunjang fungsi pompa ion yang masuk dan keluar sel sangat dipengaruhi oleh tekanan osmotik pada bahan pengencer. Tekanan osmotik ini sangat penting dalam mempertahankan keutuhan membran plasma, karena itu spermatozoa memerlukan pengencer yang bersifat isotonik. Penggunaan pengencer susu skim-kuning telur pada spermatozoa domba belum memberikan hasil fertilitas yang baik. Kondisi tersebut diduga berkaitan dengan ketidakmampuan pengencer susu skim - kuning telur untuk mencegah kerusakan membran spermatozoa yang disebabkan oleh peroksidasi lipid. Disamping itu tingginya rasio antara asam lemak jenuh dan asam lemak tidak jenuh, komposisi fosfolipid membran serta rendahnya kolesterol membuat membran spermatozoa domba mudah mengalami cold shock dan menjadi lebih rentan terhadap kerusakan akibat peroksidasi yang dapat merusak komponen struktural membran (Dasrul, 2006).

Integritas plasma membrane menurun secara bertahap sesuai dengan waktu penyimpanan. Penambahan substansi yang tidak berfungsi sebagai antioksidan (air kelapa muda) tidak dapat mencegah kerusakan plasma membrane dalam penyimpanan suhu dingin (Cesaria et al., 2019). Pada proses pendinginan menyebabkan produksi ROS meningkat (Chatterjee dan Gagnon, 2001). Antioksidan berfungsi untuk menetralkan efek merugikan ROS dalam plasma semen dan spermatozoa. Peroksidasi lipid adalah reaksi berantai yang dilakukan dalam tiga tahap: inisiasi, propagasi, dan terminasi (Repetto et al., 2012). Selama propagasi, radikal yang dibentuk oleh ROS bereaksi cepat dengan oksigen molekuler, dan kemudian menyerang molekul PUFA yang berdekatan dengan mengabstraksikan atom 
hidrogennya. PUFA awal yang sekarang telah diubah menjadi radikal akan mengabstraksi atom hidrogen dari molekul PUFA lain yang berdekatan. Siklus ini dikenal sebagai reaksi berantai, dan tidak berhenti sampai radikal membentuk produk yang tidak aktif. Dalam kondisi antioksidan habis, pencegahan seperti penambahan antioksidan ke dalam cairan semen diperlukan. Antioksidan seperti alfa-tokoferol membantu membersihkan ROS yang dihasilkan oleh rantai transpor elektron di mitokondria dari menciptakan reaksi berantai dalam membran sel. Alfa-tokoferol menghambat tahap propagasi peroksidasi lipid melalui transfer atom $\mathrm{H}$. Produk-produk reaksi adalah non-radikal dan radikal alfa tokoferoksil. Setelah radikal alfa tokoferoksil terbentuk, mereka segera bereaksi dengan radikal bebas kedua atau satu sama lain untuk membentuk produk akhir non-radikal (Hajibabaei, 2016).

\section{KESIMPULAN}

Penambahan alfa-tokoferol $0,5 \mathrm{~g} / 100 \mathrm{~mL}$ pengencer susu skim-kuning telur cukup dapat mempertahankan viabilitas, motilitas dan integritas plasma membran spermatozoa domba Sapudi dalam suhu $5^{\circ} \mathrm{C}$.

\section{DAFTAR PUSTAKA}

Arini MA, Suprayogi TW, Warsito SH, Sardjito T, Susilowati S, Triana IN. 2019. Peranan vitamin B12 dalam pengencer susu skimkuning telur terhadap motilitas dan viabilitas spermatozoa domba Sapudi postthawing. Ovozoa J Anim Reprod. 8: 110-5.

Azura S, Ratnani, Soepranianondo K, Susilowati S, Hariadi H, Samik A. 2020. Effect of $\alpha$-tocopherol supplementation in diluents on the motility, viability and plasma membrane integrity of Simmental bull spermatozoa after cooling. Ovozoa J Anim Reprod. 9: 1-6.

Bebas W, Gorda W. 2016. Penambahan Astaxanthin pada pengencer kuning telur berbagai jenis unggas dapat memproteksi semen babi selama penyimpanan. J Veteriner 17: 484-91.

Cesaria MA, Estoepangestie ATS, Susilowati S, Hernawati T, Madyawati SP, Triana IN.
2019. Pengaruh pengencer kuning telur ayam dengan air kelapa muda terhadap integritas membran plasma dan abnormalitas spermatozoa domba Sapudi. Ovozoa J Anim Reprod. 8: 139-43.

Chatterjee S, Gagnon C. 2001. Production of reactive oxygen species by spermatozoa undergoing cooling, freezing, and thawing. Mol Reprod Dev. 59: 451-58.

Dasrul D. 2006. Peran senyawa oksigen reaktif dalam mekanisme kerusakan integritas membran spermatozoa kerbau lumpur hasil sentrifugasi gradient densitas percoll. Disertasi. Program Studi Ilmu Kedokteran Pasca Sarjana Universitas Airlangga, Surabaya.

Garner DL. Hafez ESE. 2000. Spermatozoa and Seminal Plasma. In Hafez B and Hafez ESE (Eds.). Reproduction In Farm Animal. $7^{\text {th }}$ ed. Lippincott \& Wilkins, Philadelphia. 96-109

Hajibabaei K. 2016. Antioxidant properties of vitamin E. Ann Res Antioxid. 1: 1-2.

Halliwell, B. dan J.M.C. Gutteridge. 2015. Free Radicals in Biology and Medicine. $5^{\text {th }} \mathrm{Ed}$. Oxford University Press. Oxford. 9-165.

Hardijanto, Sardjito T, Hernawati T, Susilowati S, Suprayogi TW. 2010. Buku Ajar Inseminasi Buatan. Fakultas Kedokteran Hewan. Universitas Airlangga. Surabaya.

Hariyatmi. 2004. Kemampuan vitamin E sebagai antioksidan terhadap radikal bebas pada usia lanjut. J MIPA UMS 14: 52-60.

Immelda KH, Susilowati S, Yudaniayanti IS. 2019. Pengaruh bahan pengencer sari kacang kedelai (Glycine max) terhadap viabilitas dan nekrosis spermatozoa domba Sapudi. Ovozoa J Anim Reprod. 8: 36-42. Jungwirth A, Diemer T, Dohle G, Kopa Z, Krausz C, Tournaye H. 2016. Guidelines on Male Infertility. Eur Assoc Urol. 46: 124.

Khoirunnisa I, Susilowati S, Maslachah L, Suprayogi TW, Kurnijasanti R, Ratnani H. 2019. Pengaruh penambahan ekstrak teh hijau (Camellia sinensis) dalam bahan pengencer kuning telur sitrat terhadap kualitas spermatozoa domba sapudi yang disimpan pada suhu dingin. Ovozoa J Anim Reprod. 8: 127-31.

Kusumawati ED, Utomo KN, Krisnaningsih 
ATN, Rahadi S. 2017. Kualitas semen kambing Kacang dengan lama simpan yang berbeda pada suhu ruang menggunakan pengencer tris aminomethan kuning telur. JITRO 4: 42-51.

O'Connell M, McClure N, Lewis SEM. 2002. The effects of cryopreservation on sperm morphology, motility and mitochondrial function. Hum Reprod. 17: 704-9.

Ratnani H, Ihsan MN, Ciptadi G, Suyadi S. 2017. Effect of alpha-tocopherol supplementation in the extender on the sperm quality of Maduran bull before and after quick freezing. Int $\mathrm{J}$ Adv Res. 5: 1378-89.

Repetto M, Semprine J, Boveris A. 2012. Lipid Peroxidation: Chemical Mechanism, Biological Implications and Analytical Determination. Open access peer-reviewed chapter. https://doi.org/ 10.5772/45943.

Suryohudoyo P. 2000. Ilmu Kedokteran Molekuler. Cetakan Pertama. Jakarta. CV. Sagung Seto. 31- 47.

Susilawati T. 2011. Spermatologi. UB Press.
Brawijaya University. 11-14.

Susilowati S, Hardijanto, Sardjito T, Hernawati T, Suprayogi TW. 2010. Buku Ajar Inseminasi Buatan. Airlangga University Press. Surabaya.

Swari WR, Sabdoningrum EK, Wurlina W, Susilowati S, Kurnijasanti R, Safitri E. 2019. Pengaruh penambahan ekstrak teh hijau (Camellia sinensis) dalam bahan pengencer susu skim-kuning telur terhadap kualitas spermatozoa domba sapudi yang disimpan pada suhu dingin. Ovozoa J Anim Reprod. 8: 122-6.

Tremellen K. 2008. Oxidative stress and male infertility - a clinical perspective. Hum Reprod Update. 14: 243-58.

Vladika MA, Warsito SH, Susilowati S, Hernawati T, Kurnijasanti R, Restiadi TI. 2019. Pengaruh penambahan ekstrak teh hijau (Camellia sinensis) dalam bahan pengencer susu skim terhadap kualitas spermatozoa domba sapudi yang disimpan Pada suhu dingin. Ovozoa J Anim Reprod. 8: 116-21. 